\title{
Contribution of two conserved histidines to the dual activity of archaeal RNA guide-dependent and -independent pseudouridine synthase Cbf5
}

\author{
ANNE-SOPHIE TILLAULT, ${ }^{1,3,4}$ JEAN-BAPTISTE FOURMANN, ${ }^{1,3,5}$ CHRISTINE LOEGLER, ${ }^{1}$ \\ HANS-JOACHIM WIEDEN, ${ }^{2}$ UTE KOTHE, ${ }^{2}$ and BRUNO CHARPENTIER ${ }^{1}$ \\ ${ }^{1}$ Laboratoire Ingénierie Moléculaire et Physiopathologie Articulaire, UMR 7365 CNRS Université de Lorraine, Biopôle de I'Université \\ de Lorraine, Campus Biologie Santé, 54505 Vandœuvre-lès-Nancy, France \\ ${ }^{2}$ Alberta RNA Research and Training Institute, Department of Chemistry and Biochemistry, University of Lethbridge, Lethbridge, Alberta, \\ Canada T1K 3M4
}

\begin{abstract}
In all organisms, several distinct stand-alone pseudouridine synthase (PUS) family enzymes are expressed to isomerize uridine into pseudouridine $(\Psi)$ by specific recognition of RNAs. In addition, $\Psi$ s are generated in Archaea and Eukaryotes by PUS enzymes which are organized as ribonucleoprotein particles (RNP) — the box H/ACA s/snoRNPs. For this modification system, a unique TruB-like catalytic PUS subunit is associated with various RNA guides which specifically target and secure substrate RNAs by base-pairing. The archaeal Cbf5 PUS displays the special feature of exhibiting both RNA guide-dependent and -independent activities. Structures of substrate-bound TruB and H/ACA sRNP revealed the importance of histidines in positioning the target uridine in the active site. To analyze the respective role of $\mathrm{H60}$ and $\mathrm{H77}$, we have generated variants carrying alanine substitutions at these positions. The impact of the mutations was analyzed for unguided modifications $U_{55}$ in tRNA and $U_{2603}$ in 235 rRNA, and for activity of the box H/ACA Pab91 sRNP enzyme. H77 (H43 in TruB), but not H60, appeared to be crucial for the RNA guide-independent activity. In contrast to earlier suggestions, $\mathbf{H 6 0}$ was found to be noncritical for the activity of the H/ACA sRNP, but contributes together with H77 to the full activity of H/ACA sRNPs. The data suggest that a similar catalytic process was conserved in the two divergent pseudouridylation systems.
\end{abstract}

Keywords: Archaea; Cbf5; H/ACA sRNP; RNA modification; pseudouridine

\section{INTRODUCTION}

Pseudouridine $(\Psi)$ generated by isomerization of uridine is the most abundant modification found within RNAs. Until recently, $\Psi$ s have only been identified in stable RNAs as transfer, ribosomal, small nuclear and nucleolar RNAs, for which many $\Psi$ s are highly conserved and present in functionally important regions (Yu et al. 1998; Decatur and Fournier 2002; Newby and Greenbaum 2002; Badis et al. 2003; King et al. 2003; Yang et al. 2005; Ejby et al. 2007; Piekna-Przybylska et al. 2008; Karijolich and Yu 2010). Development of the high-throughput method $\Psi$-seq allowed transcriptomewide quantitative mapping of $\Psi$ s in eukaryotic RNAs, includ-

\footnotetext{
${ }^{3}$ These authors contributed equally to this work.

${ }^{4}$ Present address: Alberta RNA Research and Training Institute, Department of Chemistry and Biochemistry, University of Lethbridge, Lethbridge, Alberta, Canada T1K 3M4

${ }^{5}$ Present address: Department of Cellular Biochemistry, Max-PlanckInstitute of Biophysical Chemistry (MPI-MG), D-37077 Göttingen, Germany

Corresponding author: bruno.charpentier@univ-lorraine.fr

Article published online ahead of print. Article and publication date are at http://www.rnajournal.org/cgi/doi/10.1261/rna.051425.115.
}

ing noncoding and messenger RNAs (Carlile et al. 2014; Lovejoy et al. 2014; Schwartz et al. 2014).

Site-specific pseudouridylation is catalyzed by RNA: $\Psi$ synthase (PUS) family enzymes, which are classified based on their homology with the bacterial RluA, RsuA, TruA, TruB, TruD proteins (for review, see Hamma and FerréD'Amaré 2006), and with the archaeal Pus10 protein (Roovers et al. 2006; McCleverty et al. 2007). Alternatively, pseudouridylation is based on the action of box H/ACA ribonucleoprotein (RNP) enzymes - the box H/ACA small RNPs (sRNPs) in archaea and the box H/ACA small nucleolar and small Cajal Body-specific RNPs (snoRNAs and scaRNPs, respectively) in eukaryotes (for review, see Reichow et al. 2007; Kiss et al. 2010; Watkins and Bohnsack 2012).

Escherichia coli TruB and its homolog Pus4p in Saccharomyces cerevisiae carry out site-specific recognition and

(C) 2015 Tillault et al. This article is distributed exclusively by the RNA Society for the first 12 months after the full-issue publication date (see http://rnajournal.cshlp.org/site/misc/terms.xhtml). After 12 months, it is available under a Creative Commons License (Attribution-NonCommercial 4.0 International), as described at http://creativecommons.org/licenses/by$\mathrm{nc} / 4.0 /$. 
modification at position $\mathrm{U}_{55}$ in the loop of the TYC arm of all cellular tRNAs excluding translation initiator tRNA (Fig. 1 $\mathrm{A}_{1}$; Nurse et al. 1995; Becker et al. 1997). Several cocrystal structures of TruB associated with a tRNA fragment mimicking the TYC stem-loop identified the interactions established between TruB and its substrate RNA (Hoang and FerréD’Amaré 2001; Pan et al. 2003; Phannachet and Huang 2004). Extrusion of tRNA $U_{55}$ in the active cleft of TruB is achieved by base flipping (Hoang and Ferré-D'Amaré 2001). This process relies on histidine at amino acid position 43 (H43) in TruB, which stacks against the conserved $\mathrm{U}_{54}$ : $\mathrm{A}_{58}$ reverse Hoogsteen base pair (Fig. $1 \mathrm{~A}_{2}, \mathrm{C}_{2}$; Hoang and Ferré-D'Amaré 2001; Pan et al. 2003) and which is essential for exposing $\mathrm{U}_{55}$ (Pan et al. 2003).

Archaeal protein Cbf5 (alias aCBF5) has related features with the $E$. coli TruB enzyme as it is able to generate in vitro the universally conserved $\Psi_{55}$ in elongator tRNAs (Fig. 1 $\mathrm{A}_{1}$; Roovers et al. 2006; Gurha et al. 2007; Muller et al. 2007; Kamalampeta and Kothe 2012). A pseudouridine can also be introduced at this position by the archaeal Pus10 enzyme in vitro and in vivo (Roovers et al. 2006; Gurha and Gupta 2008; Blaby et al. 2011; Chatterjee et al. 2012; Joardar et al. 2013; Kamalampeta et al. 2013). In addition, Cbf5 in association with two interacting protein partners Nop10 and Gar1 (alias aNOP10 and aGAR1) pseudouridylates in vitro a fragment of the 23S rRNA mimicking the TYC loop of the tRNA (Muller et al. 2008). Moreover, Cbf5 is also the catalytic subunit of $\mathrm{H} /$ ACA sRNP comprising the ribosomal protein L7Ae in Archaea or Nhp2 in Eukaryotes, and proteins Nop10 and Gar1 (Fig. $1 \mathrm{~B}_{1}$ ). In the context of these RNP catalysts, the specificity for substrate recognition is carried out by the RNA component of the RNP, which defines the U to be modified by the catalytic subunit Cbf5 by base-pairing with the target sequence (for review, see Hamma and Ferré-D’Amaré 2010; Kiss et al. 2010; Watkins and Bohnsack 2012).

In agreement with the feature of the bacterial TruB enzyme, the histidine equivalent to $\mathrm{H} 43$ at position 77 ( $\mathrm{H} 77$ ) in archaeal Cbf5 is also essential for $\mathrm{U}_{55}$ tRNA modification in vitro, but does not strongly impact the activity of $\mathrm{H} /$ ACA sRNP (Muller et al. 2007). Based

$A_{1}$

$B_{1}$ on the crystallographic structure of the substrate-bound state of the H/ACA sRNP, Duan et al. (2009) proposed that histidine H60, which is conserved in Cbf5 orthologs but not in TruB orthologs, would substitute $\mathrm{H} 77$ and have a functional role in $\mathrm{U}$ extrusion into the active site of Cbf5 (Fig. $1 \mathrm{~B}_{2}$ ). This proposal is in agreement with another comparison of the free and substrate-bound H/ACA sRNP structures, which suggests that $\mathrm{H} 60$ would play an important role in coordinating substrate docking in the active site (Hamma and Ferré-
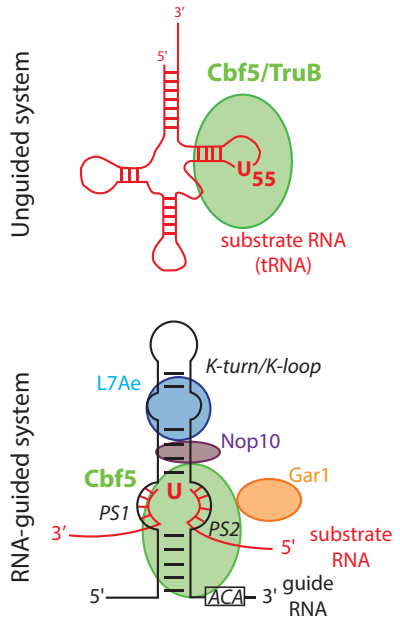

$B_{2}$
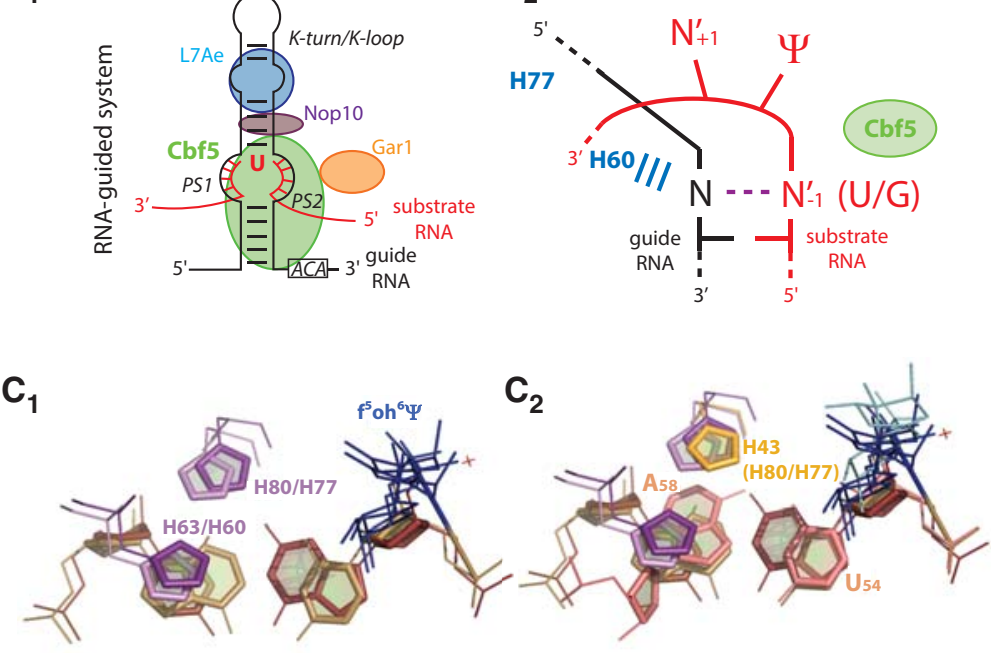

FIGURE 1. Two histidine residues in Cbf5 are proposed to contribute in the RNA-guided and unguided system. (A) Schematic views of the guide RNA-independent activity of Cbf5. $\left(A_{1}\right)$ A $2 \mathrm{D}$ representation of a substrate tRNA is shown with the target $\mathrm{U}_{55}$ in the TYC arm. $\left(A_{2}\right)$

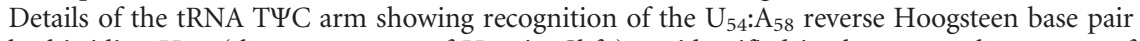
by histidine $\mathrm{H} 43$ (the counterpart of $\mathrm{H} 77$ in Cbf5), as identified in the cocrystal structure of the E. coli TruB in complex with the tRNA (Hoang and Ferré-D'Amaré 2001). (B) Schematic views of the guide RNA-dependent activity of Cbf5. $\left(B_{1}\right)$ Scheme of an archaeal box H/ACA sRNP showing the different proteins which are represented by circles, associated with the guide RNA folded as single hairpin (in black). The substrate RNA in red is shown associated with the RNP enzyme by forming two base-pair interactions with the guide RNA (PS1 and PS2). The ACA box and the K-turn/K-loop motif are indicated. $\left(B_{2}\right)$ Schematic representation of the PS2 helix formed by base-pairing of the substrate RNA with the $3^{\prime}$ strand of the pseudouridylation pocket

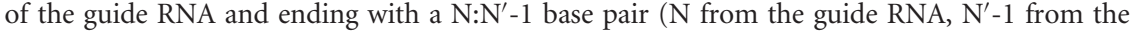
substrate RNA). Histidine $\mathrm{H} 60$ but not $\mathrm{H} 77$ was found to stack over nucleobase $A$ or $C$, corresponding to nucleotide $\mathrm{N}^{\prime}-1$, in the crystal structures of two distinct H/ACA sRNPs bound to a substrate RNA (Duan et al. 2009; Liang et al. 2009). (C) Structural alignments showing respective position of the conserved histidines in substrate-bound H/ACA sRNP enzymes. The numbering of histidines is from Pyrococcus furiosus (H63 and H80 correspond to, respectively, H60 and H77 in $P$. abyssi). The 3D structures were superposed with Swiss protein viewer and representation prepared with PyMol. $\left(C_{1}\right)$ Superposition of two H/ACA sRNPs by using the PDB access number 3 HAX (Duan et al. 2009) and 3HJW (Liang et al. 2009). The histidines are in purple and the nucleobases of the substrate are in brown and of the RNA guide in sand. $\left(C_{2}\right)$ Superposition of TruB (PDB 1K8W [Hoang and Ferré-D'Amaré 2001]) with the H/ACA sRNP enzymes. Histidine $\mathrm{H} 43$ is in orange and the $\mathrm{U}_{54}: \mathrm{A}_{58}$ reverse Hoogsteen in salmon. 
D’Amaré 2010). In addition, H60 is proposed to contribute to the recognition by Cbf5 of tRNA lacking the reverse Hoogsteen pair (Gurha et al. 2007). All these observations suggest that the RNA guide-dependent and -independent activities of Cbf5 likely rely on distinct molecular determinants. Here, by mutational analysis we investigated the respective role of the two conserved histidines H60 and H77 for the dual activity of Cbf5 from the hyperthermophilic archaeon P. abyssi. The impact of alanine substitutions of the histidines was studied for $U_{55}$ tRNA and $U_{2603}$ rRNA modifications, and for H/ACA sRNP assembly, substrate binding and pseudouridylation activity.

\section{RESULTS AND DISCUSSION}

\section{Histidine $\mathrm{H60}$ is dispensable for the RNA guide-independent activity of Cbf5}

In order to compare the functional contribution of the conserved histidine $\mathrm{H} 60$ with that of $\mathrm{H} 77$, we created variant proteins carrying a single (variant $\mathrm{H} 60 \mathrm{~A}$ and variant $\mathrm{H} 77 \mathrm{~A}$ ) or a double alanine substitution (variant H77A/H60A). We used a tritium release assay to measure time course formation of $\Psi_{55}$ in tRNA $^{\text {Asp }}$, which was synthesized and tritium-labeled at $\mathrm{C} 5$ by incorporation of $\left[5-{ }^{3} \mathrm{H}\right]$ UTP during in vitro transcription. Isomerization of uridine occurs by the breakage of the $\mathrm{C}^{\prime} 1-\mathrm{C} 1$ glycosidic bond, followed by a rotation of the uracil ring and creation of a new $\mathrm{C}^{\prime} 1-\mathrm{C} 5$ bond. The reaction was thus monitored by detecting liberation of tritium from $\mathrm{C} 5$ upon formation of the new $\mathrm{C}-\mathrm{C}$ glycosidic bond. As Cbf5 is stabilized upon binding with Nop10 and Gar1, we repeatedly measured activity of the heterotrimer Cbf5-Nop10-Gar1. In singleturnover reaction, the wild-type and the variant $\mathrm{H60A}$ efficiently modify tRNA with a similar apparent rate $k_{\text {app }}$ of 0.75 $\pm 0.31 \mathrm{~min}^{-1}$ and $0.77 \pm 0.13 \mathrm{~min}^{-1}$, respectively (Fig. 2A). Activity was significantly reduced for variant H77A ( $k_{\text {app }}$ of $0.13 \pm 0.02 \mathrm{~min}^{-1}$ ) and for variant H60A/H77A which combines the two mutations ( $k_{\text {app }}$ of $0.16 \pm 0.02 \mathrm{~min}^{-1}$ ). To monitor possible small effects of the H60A substitution in an even more sensitive system, we repeated the tRNA modification assay with the heterodimeric Cbf5-Nop10 complex. Again, the wild-type and $\mathrm{H} 60 \mathrm{~A}$ variant show similar apparent rates of $0.58 \pm 0.07 \mathrm{~min}^{-1}$ and $0.61 \pm 0.06 \mathrm{~min}^{-1}$, respectively (Fig. $2 \mathrm{~A}$ ) whereas the apparent rates variant $\mathrm{H} 77 \mathrm{~A}$ and $\mathrm{H} 60 \mathrm{~A} / \mathrm{H} 77 \mathrm{~A}$ displayed a rate reduction of more than $\sim 13$-fold $\left(k_{\text {app }}\right.$ of $0.04 \pm 0.01 \mathrm{~min}^{-1}$ and $0.04 \pm 0.01 \mathrm{~min}^{-1}$, respectively). Equivalent data were also obtained when Cbf5 was used alone (data not shown). In the presence of approximately fivefold excess of unlabeled tRNA, the multiple-turnover activity of variant $\mathrm{H} 60 \mathrm{~A}$ was comparable to that of the wild-type enzyme (Fig. 2B).

We confirmed that $\mathrm{H} 60$ does not contribute to the rRNA: $\Psi_{2603}$-synthase activity of Cbf5. The single-turnover reactions were performed in the presence of the auxiliary proteins Nop10 and Gar1 in the conditions used in a previous work (Muller et al. 2008). Mutation H77A reduced the rate of modification approximately fivefold compared with the wild-type enzyme (Fig. 2C). Hence, both RNA guide-independent activities of Cbf5 necessitate the presence of residue H77, but not of residue H60.

These data strongly suggest that the mechanism based on the contribution of a histidine, e.g., H43(H77), for accessibility of the substrate to TruB is conserved for Cbf5. In addition, the present results indicate that the two RNA guide-independent activities of Cbf5 are based on the same determinants,
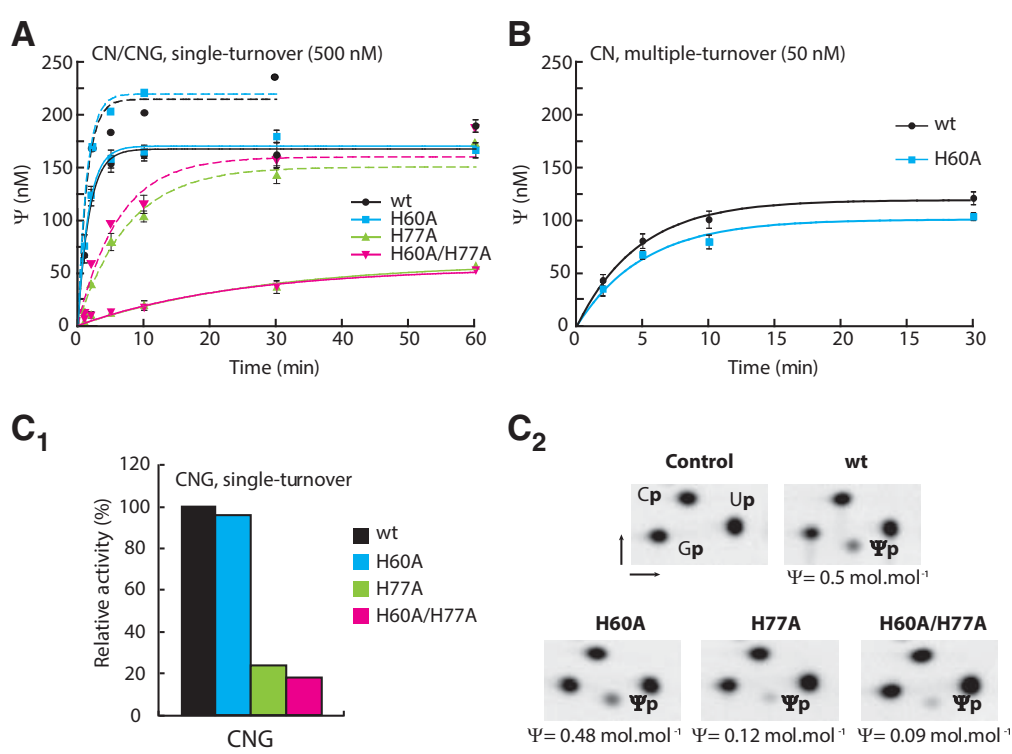

FIGURE 2. Both tRNA: $\Psi 55$ - and rRNA: $\Psi 2603$-synthase activities of Cbf5 require H77 but not H60. (A) Time course analysis of $\Psi$ formation by Cbf5 in the substrate $P$. abyssi tRNA ${ }^{\text {Asp }}$ under single-turnover conditions. The extent of $\Psi$ formation was quantified using the tritium release assay. $\left[{ }^{3} \mathrm{H}\right] \mathrm{tRNA}^{\mathrm{Asp}}(0.25 \mu \mathrm{M})$ was incubated with Cbf5 (wt, H60A, H77A, and H60A/H77A) and Nop10 (continuous lines) or Nop10 and Garl (dashed lines) at $65^{\circ} \mathrm{C}$. The concentration of the proteins was $0.5 \mu \mathrm{M}$. (B) $\Psi$ formation by Cbf5 in tRNA ${ }^{\text {Asp }}$ under multiple-turnover conditions as measured by the tritium release assay. $0.25 \mu \mathrm{M}\left[{ }^{3} \mathrm{H}\right] \mathrm{tRNA}{ }^{\text {Asp }}$ was incubated with 0.05 $\mu \mathrm{M}$ Cbf5 (wt, H60A) and Nop10. $(C)$ Analysis of $\Psi$ formation in the RNA substrate rRNA 2603 . Reactions were performed under single-turnover conditions in the presence of $30 \mathrm{nM}$ uniformly $\left[a^{-32} \mathrm{P}\right] \mathrm{CTP}$ radiolabeled $\mathrm{rRNA}_{2603}$ and $5 \mu \mathrm{M}$ of the heterotrimer composed of the wild type and variant Cbf5 enzyme (in black) and proteins Nop10 and Gar1. The reaction was performed at $65^{\circ} \mathrm{C}$ for $90 \mathrm{~min}$. $\Psi \mathrm{s}$ were detected by the nearest neighbor method and the quantities were expressed as for substrate RNA 22-U in Figure 3C. The bar graph represents the relative percentage of $\Psi$ formation compared with the wild type (panel $C_{1}$ ). The panel $C_{2}$ shows an example of 2DTLC plates with the amount of $\Psi$ formation indicated. 
and likely are based on a common mechanism. Conservation of H43 in all members of the TruB-like PUS family suggests that Cbf5 produces tRNA $\Psi_{55}$ and rRNA $\Psi_{2603}$ in vivo. As Pus10 also modifies position $U_{55}$ (Roovers et al. 2006; Gurha and Gupta 2008; Blaby et al. 2011; Kamalampeta et al. 2013), it remains to be determined whether both enzymes have redundant activities in vivo to generate tRNA $\Psi_{55}$ and $23 \mathrm{~S}$ rRNA $\Psi_{2603}$ modifications. A genetic disruption strategy in archaeon Haloferax volcanii was not able to confirm the tRNA: $\Psi_{55}$-synthase activity of Cbf5 in vivo due to the fact that disruption of the Pus10 encoding gene is not viable (Blaby et al. 2011). Hence, demonstration of the potential redundancy between activities of Pus10 and Cbf5 and the possibility to perform structure-function analysis in vivo necessitate archaeons for which gene disruption can be introduced by genetic tools and in which Pus10 and Cbf5 encoding genes are not essential for viability.

\section{The Pab91 RNP enzyme lacking either histidines H60 or H77 conserves the capacity to fully modify a substrate rRNA}

We next tested the potential contribution of H60 in the RNA guide-dependent activity of Cbf5. As shown in Figure $1 \mathrm{C}_{1}$, equivalent residue $\mathrm{H} 63$ in $P$. furiosus stacks on the guide RNA nucleobase, which is engaged in the Watson-Crick interaction with the nucleobase of the substrate RNA that precedes the target $\mathrm{U}$ (base pair $\mathrm{N}: \mathrm{N}^{\prime}-1$ in Fig. $1 \mathrm{~B}_{2}$ ). In the two crystal structures of the substrate-bound H/ACA sRNP, H63 covers the A of a A:U base pair (Duan et al. 2009) and the C of a C:G base pair (Fig. 1C $_{1}$; Liang et al. 2009). In both structures, residue $\mathrm{H} 80$ ( $\mathrm{H} 77$ in $P$. abyssi) is positioned further away from the A:U and C:G base pairs (Fig. $1 \mathrm{C}_{1}$ ). From these structures, residue $\mathrm{H} 60$ was proposed to be a key functional determinant for substrate placement in the active site of the H/ACA RNP enzyme (Hamma and Ferré-D’Amaré 2010). It was proposed that while $\mathrm{H} 60$ recognizes the canonical A: $U$ Watson-Crick pair formed between the guide RNA and the RNA substrate, H77 would stack over the tRNA $\mathrm{A}_{58}: \mathrm{U}_{54}$ reverse Hoogsteen pair which adopts a distinct orientation as compared with the guide RNA:substrate RNA canonical A:U base pair (Fig. $1 \mathrm{C}_{2}$; Duan et al. 2009).

To analyze the RNA guide-dependent activity of Cbf5, we used the H/ACA sRNP enzyme Pab91 which specifically modifies $\mathrm{U}_{2685}$ in 23S rRNA from P. abyssi (Muller et al. 2008). We first tested by EMSA the impact of the mutations on the assembly of the H/ACA sRNP (Fig. 3A). Incubation of Cbf5 (C) with the radiolabeled Pab91 guide H/ACA sRNA led to very low amounts of a stable [RNA guide:Cbf5] complex as already observed in previous works (Charpentier et al. 2005; Fourmann et al. 2013). The variant proteins bound Pab91 sRNA with the same low efficiency (compare lanes 2-5). In the presence of the core proteins L7Ae (L) and Nop10 (N) (lane 7), a major complex was formed upon binding of L7Ae on the K-loop apical structure of Pab91 but only low amounts of complex [Pab91:LCN], which corresponds to an active H/ACA sRNP enzyme, were observed (Charpentier et al. 2005). As for the [Pab91:C] complex, the mutations had no impact on the low amounts of the [Pab91:LCN] RNP enzyme (lanes 7-10). A single complex CII is formed upon addition of the unlabeled RNA substrate (Charpentier et al. 2005) (lane 11), and only the double mutation affected CII formation (lane 14), while any of the single mutation did not (lanes 12-13). To confirm these results, we tested formation of the $\mathrm{CII}^{\prime}$ complex obtained by association of the labeled RNA substrate 22-U with the RNP enzyme. The complex was detected after $10 \mathrm{~min}$ of incubation and

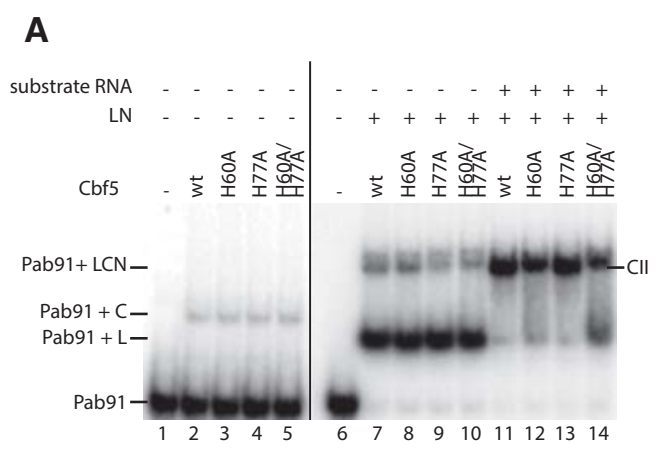

B

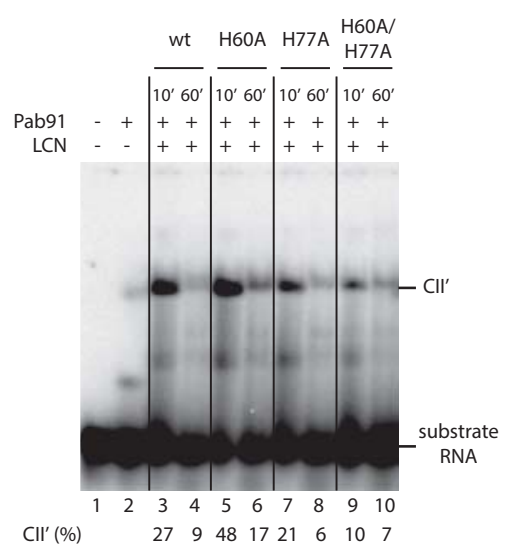

C

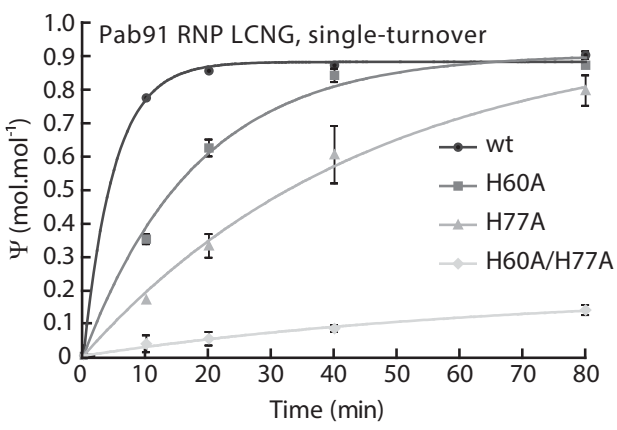

FIGURE 3. (Legend on next page) 
disappeared during the course of the reaction (Fig. 3B, lanes 3 and 4). Variants H60A or H77A formed, respectively, slightly higher ( 1.7-fold, lane 5$)$ and lower ( 0.8 -fold, lane 7$)$ complex amounts as the wild-type H/ACA sRNP enzyme (lane 3 ), but the variant $\mathrm{H} 60 \mathrm{~A} / \mathrm{H} 77 \mathrm{~A}$ conducted to approximately threefold reduction in the amounts of $\mathrm{CII}^{\prime}$ (compare lanes 3 and 9 ).

Activity of the LCNG RNP enzyme containing the full quartet of core proteins L7Ae, Cbf5, Nop10, and Gar1, was next assessed in single-turnover reactions by measurement of $\Psi$ formation by the nearest neighbor technique (Fig. 3C). Both variant RNP enzymes, H60A and H77A, completely modified RNA substrate 22-U. However, compared with the wild-type enzyme $\left(k_{\text {app }}\right.$ of $\left.0.21 \pm 0.014 \mathrm{~min}^{-1}\right)$, the rate of modification for $\mathrm{H} 60 \mathrm{~A}$ and $\mathrm{H} 77 \mathrm{~A}$ variants was lower with $k_{\text {app }}$ of $0.059 \pm 0.004 \mathrm{~min}^{-1}$ and $0.022 \pm 0.005 \mathrm{~min}^{-1}$, respectively. This corresponds, respectively, to a three to fourfold and approximately ninefold decrease to the rate of the wild-type enzyme. These data revealed that although the substitution of $\mathrm{H} 60$ or H77 did not fully impair substrate modification, substitution of $\mathrm{H} 77$ led to a slower enzyme than H60. Activity of variant H77A appeared even slower than in our previous measurements (Muller et al. 2007). The H60A/H77A variant sRNP was inactive, which was in agreement with the low amounts of $\mathrm{CII}$ and $\mathrm{CII}^{\prime}$ complexes. From these data we conclude that contrary to the deduction made by analysis of the crystal structures, residue H60 appears to not be a key functional determinant of the RNAguide-dependent activity unless $\mathrm{H} 77$ is absent.

FIGURE 3. Contribution of both histidines $\mathrm{H} 60$ and $\mathrm{H} 77$ for the guide RNA-dependent activity of Cbf5 within the Pab91 RNP. (A) Analysis by electrophoretic mobility shift assay (EMSA) of various box H/ACA subsRNPs and the complex formed between the box H/ACA sRNP and a substrate RNA. The guide RNA Pab91 which was radiolabeled at the $5^{\prime}$ end with ${ }^{32} \mathrm{P}$ was incubated with the wild type $(\mathrm{wt})$ or the variant forms of Cbf5 (variants H60A, H77A, and H60A/H77A) as indicated above each lane, alone (lanes 2-5) or in the presence of L7Ae and Nop10 (lanes 7-14) and in the absence (lanes 7-10) or the presence of the substrate RNA 22$\mathrm{U}$ (lanes 11-14). After $10 \mathrm{~min}$ incubation at $65^{\circ} \mathrm{C}$, the different complexes were fractionated by nondenaturing polyacrylamide gel electrophoresis. The identity of the sub-RNPs is indicated: C and LCN correspond, respectively, to the Pab91-Cbf5 and the Pab91-L7Ae-Cbf5-Nop10 complexes; the CII complex is formed upon association of the Pab91 LCN RNP and the substrate RNA (Charpentier et al. 2005). (B) Analysis by EMSA of the complex formed between the RNP enzyme and the substrate RNA (complex CII'). The substrate RNA 22-U which was radiolabeled at the $5^{\prime}$ end with ${ }^{32} \mathrm{P}$ was incubated with the wildtype and variant Pab91 LCN RNP assembled with the unlabeled Pab91 sRNA and the L7Ae, Cbf5, and Nop10 proteins as described in Materials and Methods. After 10 and $60 \mathrm{~min}$ at $65^{\circ} \mathrm{C}$, the different complexes were fractionated by nondenaturing polyacrylamide gel electrophoresis. (C) Time course analysis of $\Psi$ formation by the Pab91 LCNG RNP enzyme in the 22-U substrate RNA. The uniformly $\left[a^{32} \mathrm{P}\right]$ CTP radiolabeled substrate RNA $22-\mathrm{U}$ was incubated with the guide RNA Pab91 and proteins LCNG wild-type (in black), H60A (in dark gray), H77A (in gray), and H60A/H77A (in light gray) and analyzed by 1D-TLC as described in Materials and Methods. The radioactivity was quantified by PhosphorImager analysis. The quantities of $\Psi$ nucleotides formed are expressed in moles per mole of $22-\mathrm{U}$.
If the mechanism leading to $\mathrm{U}$ extrusion upon substrate base-pairing with the guide RNA necessitates the positioning of a histidine on the $\mathrm{N}$ nucleobase, the present results indicate that H77 might fulfill this role in the absence of H60. The most favorable conformation of the active site occupied by the substrate RNA is probably the one trapped in the two crystal structures (Fig. 1 $\mathrm{C}_{1}$ ). The partial supplementation of H60 by H77 would imply that the catalytic site of H/ACA sRNP possesses a degree of plasticity that could allow a repositioning of $\mathrm{H77}$ over the N nucleobase. In this scenario, the alternative conformation of the H60A variant enzyme would bind substrate with a similar efficiency as the wild-type enzyme (Fig. 3B), but would not be optimal for catalysis as slower activity was measured for the H60A sRNP variant (Fig. 3C). The structure of the active site is likely also modified in the H/ACA sRNP enzyme lacking H77 leading to a lower ability to stably bind the substrate RNA (Fig. 3B). Hence, the optimal function of $\mathrm{H} 60$ relies on the presence of H77.

\section{CONCLUSION}

Two major conclusions can be drawn from the results of the present study. First, the universally conserved histidine H77 - corresponding to H43 in the TruB enzyme-strongly contributes to the nonguided activity of the PUS Cbf5, but not H60 which is conserved in only the Cbf5-like PUS. Second, optimal activity of the H/ACA sRNP enzyme necessitates presence of both histidines H60 and H77. Among the two histidines, only H77 represents a common determinant for the RNA guide-dependent and -independent activities. These data suggest that during evolution, molecular determinants were conserved for the two divergent modes of PUS activity. Knowledge on the 3D structure adopted by the substratebound variant H60A and H77A H/ACA sRNP enzymes would help to refine our appreciation on the organization and plasticity of active site of the PUS enzymes.

\section{MATERIALS AND METHODS}

\section{Protein expression and purification}

The recombinant proteins were produced in Escherichia coli BL21 (DE3) (Stratagene) as GST-fusion proteins from recombinant pGEX-6P1 plasmids and purified as described previously (Charpentier et al. 2005; Muller et al. 2007). Site-directed mutagenesis based on PCR was used to prepare the plasmid variants encoding proteins Cbf5 H60A, H77A, and H60A/H77A. For the H77A substitution, the PCR reaction was performed with the plasmid pGEX$6 \mathrm{P} 1-\mathrm{Cbf5}$ as the template and with two primers carrying the substitution (forward: 5'-GGTCGAGGGTTCCACCAGCACCGGCTTT CTCCAAGTT- $3^{\prime}$ and reverse: 5'-AACTTGGAGAAAGCCGGTGC TGGTGGAACCCTCGACC- $3^{\prime}$ ). For the H60A and H60A/H77A substitutions, the PCR reactions were realized with the plasmids pGEX-6P1-Cbf5 and Cbf5 H77A, respectively, and two primers carrying the substitutions (forward: 5'-GCCCTACTAGCGCTGAGG 
TCGTTGC-3' and reverse: 5'-GCAACGACCTCAGCGCTAGTA GGGC-3'). The nucleotides corresponding to the substituted codon are indicated in bold.

\section{In vitro transcription of the tRNA ${ }^{\mathrm{Asp}}$, the guide RNA Pab91 and its target RNA 22-U}

The DNA template used for in vitro transcription of the various RNAs, i.e., the P. abyssi Pab91 guide RNA and tRNA ${ }^{\text {Asp }}$, were obtained by PCR amplification with the forward primer generating the sequence of the T7 promoter as previously described (Charpentier et al. 2005, 2007; Muller et al. 2007, 2008; Kamalampeta et al. 2013). The template for synthesis of the substrate RNA 22-U and the $23 \mathrm{~S}$ rRNA fragment $\mathrm{rRNA}_{2603}$ were obtained by hybridization of two complementary oligodeoxyribonucleotides, i.e., 5'-TAA TACGACTCACTATAGGGTTTAGACCGTCGTGAGAGA-3' and 5'-TCTCTCACGACGGTCTAAACCCTATAGTGAGTCGTATTA-3' for 22-U, and 5'-TAATACGACTCACTATAGGGCTGTCGGCTCTT CCCAT- $3^{\prime}$ and $5^{\prime}$-ATGGGAAGAGCCGACAGCCCTATAGTGAGT CGTATTA-3' for $\mathrm{rRNA}_{2603}$, with the $\mathrm{T}$ corresponding to the target $\mathrm{U}$ in the coding strand indicated in bold and the sequence of the T7 promoter in italic. RNAs 22-U and $\mathrm{rRNA}_{2603}$ correspond to two fragments of the $23 \mathrm{~S}$ rRNA encompassing, respectively, nucleotides $\mathrm{U}_{2685}$ and $\mathrm{U}_{2603}$. Conditions for the reactions of in vitro transcription and purification were performed as detailed previously (Charpentier et al. 2007; Kamalampeta and Kothe 2012). The substrate RNAs 22-U and $\mathrm{rRNA}_{2603}$ used for activity measurements were radiolabeled during transcription in the presence of $\left[a-{ }^{32} \mathrm{P}\right] \mathrm{CTP}$.

The in vitro transcription of radiolabeled tRNA ${ }^{\text {Asp }}$ was performed in the presence of $3 \mathrm{mM}$ (ATP, CTP, and GTP) and $0.1 \mathrm{mM}\left[5-{ }^{3} \mathrm{H}\right]$ UTP.

\section{H/ACA sRNP enzyme reconstitution}

As previously described (Charpentier et al. 2007), the box H/ACA sRNPs were reconstituted either by incubation of 2 pmol of unlabeled or $50 \mathrm{fmol}$ of labeled Pab91 RNA with $0.2-1 \mu \mathrm{M}$ of recombinant proteins in buffer D (20 mM HEPES KOH pH 7.9, $150 \mathrm{mM}$ $\mathrm{KCl}, 1.5 \mathrm{mM} \mathrm{MgCl}_{2}$, and $0.2 \mathrm{mM} \mathrm{EDTA}$ ), and in the presence of competitor tRNA (250 ng) at $65^{\circ} \mathrm{C}$.

\section{Analysis of H/ACA sRNP enzyme:substrate complex formation, and activity measurement}

Two approaches were used. The RNPs assembled with the radiolabeled guide RNA Pab91 were incubated with unlabeled 22-U ( 2 pmol) leading to CII complex formation (Charpentier et al. 2005). In the second procedure, complex CII' was formed by association of the radiolabeled substrate $22-\mathrm{U}$ RNA $(\sim 0.03 \mu \mathrm{M})$ with the H/ACA sRNP $(\sim 0.45 \mu \mathrm{M})$ reconstituted with unlabeled guide RNA Pab91 (Charpentier et al. 2005, 2007; Fourmann et al. 2013). The complexes were fractionated by nondenaturing polyacrylamide gel electrophoresis and visualized with a PhosphorImager (Typhoon 9410, Amersham Biosciences). The radioactivity present in complexes CII and CII' or in the unbound fraction was quantified using the ImageQuant software Version 5.2 (Molecular Dynamics). The percentage of RNA in the slower migrating complex was calculated from the radioactivity in each band relative to the total radioactivity in the lane.
RNA: $\Psi$-synthase activity of the reconstituted sRNP Pab91 was measured by using the nearest neighbor method and the conditions for time course analysis of single-turnover reactions were as previously described (Charpentier et al. 2005; Fourmann et al. 2013). Briefly, unlabeled guide RNA $(\sim 0.5 \mu \mathrm{M})$ and $150 \mathrm{fmol}(\sim 0.03$ $\mu \mathrm{M})$ of $\left[\alpha^{-32} \mathrm{P}\right] \mathrm{CTP}$ labeled substrate RNA were mixed at $65^{\circ} \mathrm{C}$ with protein combinations LCN (L7Ae-Cbf5-Nop10) or LCNG (L7Ae-Cbf5-Nop10-Gar1) (1-3 $\mu \mathrm{M})$. Aliquots were collected at several time points and the reaction was stopped by phenol-chloroform extraction followed by ethanol precipitation. The recovered RNA substrates were digested with 0.4 units of RNase T2 to generate $3^{\prime}$ phospho-mononucleotide. The resulting mononucleotides were fractionated by mono- or bidimensional thin layer chromatography, and the radioactivity in the resulting bands was quantified with a PhosphorImager using the ImageQuant software. The quantities of $\Psi$ residues formed were determined as described before (Charpentier et al. 2007). The obtained values in moles of $\Psi$ per mole of substrate RNA (mol.mol ${ }^{-1}$ ) were analyzed with the Prism software Version 5.04 (GraphPad). Initial rates of $\Psi$ formation and extents of the reaction were determined from at least three independent experiments. The single-turnover experiments were analyzed by fitting the data with a single-exponential equation and initial rates $k_{\text {app }}$ correspond to the slope of the curve for the 0-5-min interval.

\section{Tritium release assay}

The pseudouridylation activity measurements were performed in buffer $\mathrm{D}$ at $65^{\circ} \mathrm{C}$ as described previously (Kamalampeta and Kothe 2012). $250 \mathrm{nM}$ of $\left[{ }^{3} \mathrm{H}\right] \mathrm{tRNA}^{\mathrm{Asp}}$ were incubated in the presence of $500 \mathrm{nM}$ or $50 \mathrm{nM}$ of proteins Cbf5-Nop10 for single- and multiple-turnover, respectively. Samples were collected from the reaction at different times, and proteins and tRNA were removed by two extractions with 5\% (w/v) activated charcoal (Norit A, EMD, CX06551) in $0.1 \mathrm{M} \mathrm{HCl}$. The supernatant was further cleared by filtration through glass wool. After adding EcoLite scintillation cocktail, the quantity of $\left[{ }^{3} \mathrm{H}\right]$ in the final solution was estimated by scintillation counting. Each experiment was repeated at least twice and results were fit with an exponential equation as it was done for the RNA guide-dependent activity.

\section{ACKNOWLEDGMENTS}

This work was supported by the Agence Nationale de la Recherche (ANR-08-BLAN-0036-01), the French Ministère de l'Enseignement Supérieur et de la Recherche (doctoral fellowship to A.-S.T. and J.-B.F.), the Centre National de la Recherche Scientifique, and the University of Lorraine (UL), the Pôle de Recherche Scientifique et Technologique IMTS of Région Lorraine, the Natural Sciences and Engineering Research Council of Canada (U.K.), the Canada Foundation for Innovation (U.K. and H.-J.W.), and Alberta Innovates-Technology Futures (H.-J.W.).

Received February 15, 2015; accepted April 9, 2015.

\section{REFERENCES}

Badis G, Fromont-Racine M, Jacquier A. 2003. A snoRNA that guides the two most conserved pseudouridine modifications within rRNA confers a growth advantage in yeast. RNA 9: 771-779. 
Becker HF, Motorin Y, Planta RJ, Grosjean H. 1997. The yeast gene YNL292w encodes a pseudouridine synthase (Pus4) catalyzing the formation of $\Psi_{55}$ in both mitochondrial and cytoplasmic tRNAs. Nucleic Acids Res 25: 4493-4499.

Blaby IK, Majumder M, Chatterjee K, Jana S, Grosjean H, de CrécyLagard V, Gupta R. 2011. Pseudouridine formation in archaeal RNAs: the case of Haloferax volcanii. RNA 17: 1367-1380.

Carlile TM, Rojas-Duran MF, Zinshteyn B, Shin H, Bartoli KM, Gilbert WV. 2014. Pseudouridine profiling reveals regulated mRNA pseudouridylation in yeast and human cells. Nature 515: 143-146.

Charpentier B, Muller S, Branlant C. 2005. Reconstitution of archaeal $\mathrm{H} / \mathrm{ACA}$ small ribonucleoprotein complexes active in pseudouridylation. Nucleic Acids Res 33: 3133-3144.

Charpentier B, Fourmann JB, Branlant C. 2007. Reconstitution of archaeal H/ACA sRNPs and test of their activity. Methods Enzymol 425: 389-405.

Chatterjee K, Blaby IK, Thiaville PC, Majumder M, Grosjean H, Yuan YA, Gupta R, de Crécy-Lagard V. 2012. The archaeal COG1901/ DUF358 SPOUT-methyltransferase members, together with pseudouridine synthase Pus10, catalyze the formation of 1-methylpseudouridine at position 54 of tRNA. RNA 18: 421-433.

Decatur WA, Fournier MJ. 2002. rRNA modifications and ribosome function. Trends Biochem Sci 27: 344-351.

Duan J, Li L, Lu J, Wang W, Ye K. 2009. Structural mechanism of substrate RNA recruitment in H/ACA RNA-guided pseudouridine synthase. Mol Cell 34: 427-439.

Ejby M, Sørensen MA, Pedersen S. 2007. Pseudouridylation of helix 69 of $23 \mathrm{~S}$ rRNA is necessary for an effective translation termination. Proc Natl Acad Sci 104: 19410-19415.

Fourmann JB, Tillault AS, Blaud M, Leclerc F, Branlant C, Charpentier B. 2013. Comparative study of two box H/ACA ribonucleoprotein pseudouridine-synthases: relation between conformational dynamics of the guide RNA, enzyme assembly and activity. PLoS One 8: e70313.

Gurha P, Gupta R. 2008. Archaeal Pus10 proteins can produce both pseudouridine 54 and 55 in tRNA. RNA 14: 2521-2527.

Gurha P, Joardar A, Chaurasia P, Gupta R. 2007. Differential roles of archaeal box H/ACA proteins in guide RNA-dependent and independent pseudouridine formation. RNA Biol 4: 101-109.

Hamma T, Ferré-D’Amaré AR. 2006. Pseudouridine synthases. Chem Biol 13: 1125-1135.

Hamma T, Ferré-D’Amaré AR. 2010. The box H/ACA ribonucleoprotein complex: interplay of RNA and protein structures in post-transcriptional RNA modification. J Biol Chem 285: 805-809.

Hoang C, Ferré-D’Amaré AR. 2001. Cocrystal structure of a tRNA $\Psi 55$ pseudouridine synthase: nucleotide flipping by an RNA-modifying enzyme. Cell 107: 929-939.

Joardar A, Jana S, Fitzek E, Gurha P, Majumder M, Chatterjee K, Geisler M, Gupta R. 2013. Role of forefinger and thumb loops in production of $\Psi 54$ and $\Psi 55$ in tRNAs by archaeal Pus10. RNA 19: 1279-1294.

Kamalampeta R, Kothe U. 2012. Archaeal proteins Nop10 and Gar1 increase the catalytic activity of Cbf5 in pseudouridylating tRNA. Sci Rep 2: 663.

Kamalampeta R, Keffer-Wilkes LC, Kothe U. 2013. tRNA binding, positioning, and modification by the pseudouridine synthase Pus10. J Mol Biol 425: 3863-3874.

Karijolich J, Yu YT. 2010. Spliceosomal snRNA modifications and their function. RNA Biol 7: 192-204.
King TH, Liu B, McCully RR, Fournier MJ. 2003. Ribosome structure and activity are altered in cells lacking snoRNPs that form pseudouridines in the peptidyl transferase center. Mol Cell 11: 425-435.

Kiss T, Fayet-Lebaron E, Jády BE. 2010. Box H/ACA small ribonucleoproteins. Mol Cell 37: 597-606.

Liang B, Zhou J, Kahen E, Terns RM, Terns MP, Li H. 2009. Structure of a functional ribonucleoprotein pseudouridine synthase bound to a substrate RNA. Nat Struct Mol Biol 16: 740-746.

Lovejoy AF, Riordan DP, Brown PO. 2014. Transcriptome-wide mapping of pseudouridines: pseudouridine synthases modify specific mRNAs in S. cerevisiae. PLoS One 9: el10799.

McCleverty CJ, Hornsby M, Spraggon G, Kreusch A. 2007. Crystal structure of human Pus10, a novel pseudouridine synthase. J Mol Biol 373: 1243-1254.

Muller S, Fourmann JB, Loegler C, Charpentier B, Branlant C. 2007. Identification of determinants in the protein partners aCBF5 and aNOP10 necessary for the tRNA: 455 -synthase and RNA-guided RNA: $\Psi$-synthase activities. Nucleic Acids Res 35: 5610-5624.

Muller S, Leclerc F, Behm-Ansmant I, Fourmann JB, Charpentier B, Branlant C. 2008. Combined in silico and experimental identification of the Pyrococcus abyssi H/ACA sRNAs and their target sites in ribosomal RNAs. Nucleic Acids Res 36: 2459-2475.

Newby MI, Greenbaum NL. 2002. Sculpting of the spliceosomal branch site recognition motif by a conserved pseudouridine. Nat Struct Biol 9: $958-965$.

Nurse K, Wrzesinski J, Bakin A, Lane BG, Ofengand J. 1995. Purification, cloning, and properties of the tRNA $\Psi 55$ synthase from Escherichia coli. RNA 1: 102-112.

Pan H, Agarwalla S, Moustakas DT, Finer-Moore J, Stroud RM. 2003. Structure of tRNA pseudouridine synthase TruB and its RNA complex: RNA recognition through a combination of rigid docking and induced fit. Proc Natl Acad Sci 100: 12648-12653.

Phannachet K, Huang RH. 2004. Conformational change of pseudouridine 55 synthase upon its association with RNA substrate. Nucleic Acids Res 32: 1422-1429.

Piekna-Przybylska D, Przybylski P, Baudin-Baillieu A, Rousset JP, Fournier MJ. 2008. Ribosome performance is enhanced by a rich cluster of pseudouridines in the A-site finger region of the large subunit. J Biol Chem 283: 26026-26036.

Reichow SL, Hamma T, Ferré-D’Amaré AR, Varani G. 2007. The structure and function of small nucleolar ribonucleoproteins. Nucleic Acids Res 35: 1452-1464.

Roovers M, Hale C, Tricot C, Terns MP, Terns RM, Grosjean H, Droogmans L. 2006. Formation of the conserved pseudouridine at position 55 in archaeal tRNA. Nucleic Acids Res 34: 4293-4301.

Schwartz S, Bernstein DA, Mumbach MR, Jovanovic M, Herbst RH, León-Ricardo BX, Engreitz JM, Guttman M, Satija R, Lander ES, et al. 2014. Transcriptome-wide mapping reveals widespread dynamic-regulated pseudouridylation of ncRNA and mRNA. Cell 159: $148-162$.

Watkins NJ, Bohnsack MT. 2012. The box C/D and H/ACA snoRNPs: key players in the modification, processing and the dynamic folding of ribosomal RNA. Wiley Interdiscip Rev RNA 3: 397-414.

Yang C, McPheeters DS, Yu YT. 2005. $\Psi 35$ in the branch site recognition region of $\mathrm{U} 2$ small nuclear RNA is important for pre-mRNA splicing in Sacharomyces cerevisiae. J Biol Chem 280: 6655-6662.

Yu YT, Shu MD, Steitz JA. 1998. Modifications of U2 snRNA are required for snRNP assembly and pre-mRNA splicing. EMBO J 17: 5783-5795. 

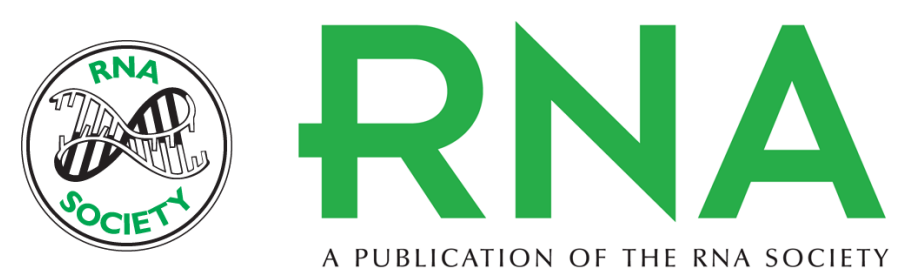

A PUBLICATION OF THE RNA SOCIETY

\section{Contribution of two conserved histidines to the dual activity of archaeal RNA guide-dependent and -independent pseudouridine synthase Cbf5}

Anne-Sophie Tillault, Jean-Baptiste Fourmann, Christine Loegler, et al.

RNA 2015 21: 1233-1239 originally published online May 19, 2015

Access the most recent version at doi:10.1261/rna.051425.115

References This article cites 38 articles, 12 of which can be accessed free at: http://rnajournal.cshlp.org/content/21/7/1233.full.html\#ref-list-1

Creative This article is distributed exclusively by the RNA Society for the first 12 months after the Commons License full-issue publication date (see http://rnajournal.cshlp.org/site/misc/terms.xhtml). After 12 months, it is available under a Creative Commons License (Attribution-NonCommercial 4.0 International), as described at http://creativecommons.org/licenses/by-nc/4.0/.

Email Alerting
Service

Receive free email alerts when new articles cite this article - sign up in the box at the top right corner of the article or click here. 